\title{
Conversion of methionine to phytotoxic 3-methylthiopropionic acid by Xanthomonas campestris pv. manihotis
}

\author{
E. EWBanK* and H. Maraite \\ Laboratoire de Phytopathologie, Université Catholique de Louvain, Place Croix du Sud, 3, Sc 15 D0, \\ B-1348 Louvain-la-Neuve, Belgium
}

(Received 12 February 1990; accepted 2 April 1990)

\begin{abstract}
Incubation of the plant pathogenic bacterium Xanthomonas campestris pv. manihotis with either L-[3,4$\left.{ }^{14} \mathrm{C}\right]$ methionine or $\left[3,4-{ }^{14} \mathrm{C} \mid \mathrm{KMBA}\right.$ (2-keto-4-methylthiobutyric acid) led to the production of $\left[{ }^{14} \mathrm{C}\right] \mathrm{MTPA}(3-$ methylthiopropionic acid) and $\mid{ }^{14}$ CIMTAA (3-methylthioacrylic acid). When an excess of non-radioactive KMBA was present in the medium, formation of $\left[{ }^{14} \mathrm{C}\right] \mathrm{KMBA}$ from $\mathrm{L}-\left[3,4-{ }^{14} \mathrm{C}\right]$ methionine was observed. Conversely, $\left[{ }^{14} \mathrm{C}\right]$ methionine accumulated in a trapping pool of non-radioactive methionine as a result of biotransformation of [3,4-14 $\mathrm{C} \mid \mathrm{KMBA}$. Aminooxyacetic acid, a transaminase inhibitor, suppressed totally the formation of $\left[{ }^{14} \mathrm{C}\right] \mathrm{MTPA}$ from L-[3,4-14 C]methionine but not from $\left[3,4-{ }^{14} \mathrm{C}\right] \mathrm{KMBA}$. Metabolism of $\mathrm{L}-\left[1-{ }^{14} \mathrm{C}\right]$ methionine liberated ${ }^{14} \mathrm{CO}_{2}$ but did not produce $\left[{ }^{14} \mathrm{C}\right]$ MTPA. These results demonstrate that methionine is catabolized by $X$. campestris pv. manihotis into MTPA via transamination and subsequent decarboxylation of the intermediate $\alpha$-keto acid KMBA.
\end{abstract}

\section{Introduction}

Cassava (Manihot esculenta Crantz) bacterial blight, caused by Xanthomonas campestris pv. manihotis (Berthet \& Bondar, 1915; Young et al., 1978) is characterized by water-soaked angular leaf spots which often develop rapidly into extensive blight areas (Maraite \& Meyer, 1975). From such lesions, the blight-inducing toxin 3methylthiopropionic acid (MTPA) was isolated by Perreaux et al. (1986).

In broth media supplemented with methionine, MTPA is produced by $X$. campestris pv. manihotis (Perreaux et al., 1982) and several other pathovars of $X$. campestris (Noda et al., 1980; Robeson \& Cook, 1985). Although it is known that methionine undergoes biotransformation to MTPA (Arima et al., 1970; Robeson \& Cook, 1985), the precise reaction sequence is still unknown for the species of prokaryotes studied. In the case of mammalian liver cells, the catabolism of methionine has been described by Case \& Benevenga (1976). In this system, the amino acid was first deaminated to produce 2-keto-4-methylthiobutyric acid (KMBA) which was subsequently decarboxylated into MTPA (Steele \& Benevenga, 1978; Dixon \& Benevenga,

\footnotetext{
Abbreviations: AOAA, aminooxyacetic acid; MTAA, 3-methylthioacrylic acid; MTPA, 3-methylthiopropionic acid; KMBA, 2-keto-4methylthiobutyric acid.
}

1980). In this paper, our purpose is to establish the occurrence of such a catabolic sequence in a plant pathogenic bacterium such as $X$. campestris.

\section{Methods}

Chemicals. Glutamic acid, methionine, cysteine, all chemical salts used in the different broth culture and all solvents (analytical or HPLC grade) were purchased from Merck. Yeast extract was obtained from Difco; 2-keto-4-methylthiobutyric acid (KMBA), aminooxyacetic acid (AOAA), reduced glutathione, amino acid oxidase type I from Crotalus adamanteus and catalase were obtained from Sigma. 3-Methylthiopropionic acid (MTPA) was synthesized according to Holmberg (1945) and 3-methylthioacrylic acid (MTAA) was provided by Dr T. Noda (Laboratory of Plant Pathology, Joetsu, Niigata 943-01, Japan). Na-S HiPhi Diluent $(0 \cdot 2 \mathrm{M}$-sodium citrate buffer, $\mathrm{pH} 2 \cdot 2 \pm 0 \cdot 01)$, used for sample preparation before amino acid analysis, was purchased from Dionex. Pic-Reagent A (tetrabutylammonium phosphate) for ionpairing in HPLC and Sep-Pak C18 for sample preparation were from Waters. The radiolabelled compounds $\mathrm{L}-\left[3,4-{ }^{14} \mathrm{C}\right]$ methionine [specific activity $\left.56 \mathrm{mCi} \mathrm{mmol}^{-1}\left(2.07 \mathrm{TBq} \mathrm{mmol}{ }^{-1}\right)\right]$ and $\mathrm{L}-\left[1-^{-14} \mathrm{C}\right]$ methionine [specific activity $52 \mathrm{mCi} \mathrm{mmol}^{-1}\left(1.92 \mathrm{TBq} \mathrm{mmol}^{-1}\right)$ ] were provided by CEA. Labelled $\left[3,4^{-14} \mathrm{C}\right] \mathrm{KMBA}$ was prepared and purified, using the procedure of Mitchell \& Benevenga (1978), by incubating [3,4${ }^{14} \mathrm{C}$ ]methionine with 1 unit of L-amino acid oxidase and 800 units of catalase. Purity was checked by HPLC and radioactivity measurements were made on collected fractions, as described below. Lumagel scintillation fluid (Lumac) was used for liquid scintillation counting.

Bacterial cultures. All experiments were done with strain HMB 23 (BM 12, ICPB XM 147) of X. campestris pv. manihotis. The strain was stored at room temperature on GYCA medium (Dye, 1962). For 
inoculum production, bacteria were grown in GYS broth (per litre, $5.0 \mathrm{~g}$ glucose, $0.5 \mathrm{~g} \mathrm{NH}_{4} \mathrm{H}_{2} \mathrm{PO}_{4}, 1.5 \mathrm{~g} \mathrm{~K}_{2} \mathrm{HPO}_{4}, 0.2 \mathrm{~g} \mathrm{MgCl}_{2} .6 \mathrm{H}_{2} \mathrm{O}$, $5.0 \mathrm{~g} \mathrm{NaCl}, 5.0 \mathrm{~g}$ yeast extract). Culture samples $(0.25 \mathrm{ml})$ harvested after $48 \mathrm{~h}$ at the end of the exponential growth phase were used to inoculate $50 \mathrm{ml}$ of broth medium in $250 \mathrm{ml}$ Erlenmeyer flasks. The basic culture medium used was a modified Watanabe broth (Watanabe et al., 1967) [per litre, $1.0 \mathrm{~g}(6.80 \mathrm{mM}) \mathrm{L}$-glutamic acid, $0.5 \mathrm{~g}(3.35 \mathrm{mM}) \mathrm{L}-$

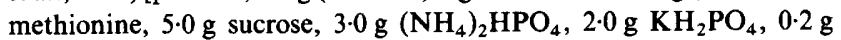
$\mathrm{MgCl}_{2} .6 \mathrm{H}_{2} \mathrm{O}, 0.01 \mathrm{~g} \mathrm{FeSO}_{4} .7 \mathrm{H}_{2} \mathrm{O}, 0.01 \mathrm{~g} \mathrm{MnSO}_{4} . \mathrm{H}_{2} \mathrm{O}$ ]. For some cultures, the methionine in the basic medium was replaced by $0.40 \mathrm{~g}$ (3.30 mM) L-cysteine $1^{-1}$ or $0.47 \mathrm{~g}(3.30 \mathrm{~mm})$ sodium sulphate $\mathrm{l}^{-1}$. Cultures were incubated for $84 \mathrm{~h}$ at $28^{\circ} \mathrm{C}$ on a gyratory shaker operating at 150 r.p.m. (radius of motion $3 \mathrm{~cm}$ ). Growth was estimated by optical density measurements at $600 \mathrm{~nm}$. At regular intervals during growth, $2 \mathrm{ml}$ samples were taken aseptically, bacteria were pelleted by centrifugation $(10000 \mathrm{~g}$ for $15 \mathrm{~min})$ and supernatants were assayed for organic acids and/or amiris acids.

Preparation of bacterial suspension. Cells from $50 \mathrm{ml}$ cultures in modified Watanabe broth were harvested after $48 \mathrm{~h}$ by centrifugation $(10000 \mathrm{~g}$ for $15 \mathrm{~min})$, washed twice with $50 \mathrm{ml} 20 \mathrm{mM}$-potassium phosphate buffer, $\mathrm{pH} 7 \cdot 2$, and resuspended in an adequate volume of the same buffer to obtain approximately $2 \times 10^{10}$ bacteria $\mathrm{ml}^{-1}$, as determined by counting in a Petroff-Hausser cell. Protein was determined by the biuret procedure as modified by Stickland (1951); BSA was used as a standard. The bacterial suspension was used immediately in subsequent experiments involving incubation with labelled compounds.

Incubation of bacterial suspension. Bacterial suspension $(0.5 \mathrm{ml})$ was incubated in $25 \mathrm{ml}$ Erlenmeyer flasks containing $0.5 \mathrm{ml}$ of an incubation mixture. Two different mixtures were used. The first contained $8 \mathrm{mM}-\mathrm{L}-\left[3,4-{ }^{14} \mathrm{C}\right]$ methionine $[2 \mu \mathrm{Ci}(74 \mathrm{kBq})], 8 \mathrm{~mm}$-potassium phosphate buffer (pH 7.2) and 0 or 4 mM-KMBA. The second contained $5 \mathrm{mM}-\left[3,4^{-14} \mathrm{C}\right] \mathrm{KMBA}[0.5 \mu \mathrm{Ci}(18.5 \mathrm{kBq})], 8 \mathrm{mM}$-potassium phosphate buffer ( $\mathrm{pH} 7.2)$ and 0 or $4 \mathrm{mM}-\mathrm{L}$-methionine. The effect of AOAA $(0.2 \mathrm{~mm})$ was determined for both mixtures. After $2 \mathrm{~h}$, incubations were stopped by addition of $0.5 \mathrm{ml} 2 \mathrm{M}-\mathrm{HClO}_{4}$; bacteria were pelleted by centrifugation $(10000 \mathrm{~g}$ for $15 \mathrm{~min}$ ) and radioactivity in the supernatant was determined by liquid scintillation counting of HPLC fractions.

Decarboxylation of methionine was measured by radiorespirometry, using the procedure described by Mayaudon (1971). The bacterial suspensions $(0.5 \mathrm{ml})$ were mixed with $1 \mu \mathrm{Ci}(37 \mathrm{kBq}) \mathrm{L}-\left[1-{ }^{14} \mathrm{C}\right]$ methionine, $1 \mu \mathrm{mol} \mathrm{L}$-methionine and $4 \mu \mathrm{mol}$ potassium phosphate buffer $(\mathrm{pH} \mathrm{7.2)}$ in a final volume of $1 \mathrm{ml}$, and incubated in a thermostatic $10 \mathrm{ml}$ reactor connected by a closed loop to a Cary $401 \beta$-counter (Varian). The atmosphere in the head-space of the reactor was forced, with a peristaltic pump, through the detector chamber and the accumulation of the released ${ }^{14} \mathrm{CO}_{2}$ was measured for $1.5 \mathrm{~h}$. Experiments were done at various temperatures between 10 and $30^{\circ} \mathrm{C}$.

Chromatographic procedures. Methionine and glutamic acid were assayed by ion-exchange chromatography and post-column derivatization with ninhydrin, using a Dionex Amino Acid Analyzer D300, according to the standard procedure of Spackman et al. (1958). Samples from broth culture $(2 \mathrm{ml})$ were mixed with $8 \mathrm{ml}$ methanol. The resulting polysaccharide precipitate was removed by filtration through a $0.45 \mu \mathrm{m}$ ( $25 \mathrm{~mm}$ diameter) Schleicher and Schuell filter; $1 \mathrm{ml}$ of the filtrate was dried thoroughly under vacuum and redissolved in $20 \mathrm{ml}$ of Na-S HiPhi Diluent buffer before being analysed.

HPLC was used to quantify simultaneously MTPA, MTAA and KMBA released into the broth culture. The non-destructive UV detection also allowed further measurements by liquid scintillation counting on eluted fractions when ${ }^{14} \mathrm{C}$-labelled compounds were used. Separation of carboxylic acids was done by the ion-pairing technique on a Rosil C18 reverse-phase column (length $250 \mathrm{~mm}$, internal diam. $4.6 \mathrm{~mm}$ ) obtained from Alltech. The HPLC system also comprised a Waters 510 pump, a Rheodyne 7125 injector valve and a Waters Lambda-Max 481 spectrophotometer detector. The elution solvent was water/acetonitrile $(92: 8, \mathrm{v} / \mathrm{v})$. The ion-pairing agent $(8.5 \mathrm{ml}$ of PicReagent A per litre of water) was dissolved in the water before addition of acetonitrile. Elution was isocratic with a flow rate of $1 \mathrm{ml} \mathrm{min}-1$; detection was at $210 \mathrm{~nm}$; chromatogram recording and peak integration were done with the software Baseline 810 (Waters). Samples were purified by liquid-solid extraction on a Sep-Pak C18 cartridge. The C18 solid phase was conditioned by successive washings with $5 \mathrm{ml}$ methanol and $5 \mathrm{ml} 10 \mathrm{mM}-\mathrm{H}_{3} \mathrm{PO}_{4}$. After acidification to $\mathrm{pH} 2$ with $2 \mathrm{M}-\mathrm{H}_{3} \mathrm{PO}_{4}$ the sample $(2 \mathrm{ml})$ was passed through the Sep-Pak. The C18 adsorbent was then washed with $2 \mathrm{ml} 10 \mathrm{~mm}-\mathrm{H}_{3} \mathrm{PO}_{4}$ and carboxylic acids of interest were eluted with $2 \mathrm{ml} 20 \mathrm{~mm}$-potassium phosphate buffer $(\mathrm{pH} 7)$ and acetonitrile $(80: 20, \mathrm{v} / \mathrm{v})$. When radioactivity measurements were to be done after HPLC separation, the elution solvent coming out of the detector was collected every $12 \mathrm{~s}$ in $3 \mathrm{ml}$ glass tubes. Lumagel $(2 \mathrm{ml})$ was added to each tube and radioactivity was measured by liquid scintillation counting on a Beckman LS 1701.

\section{Results}

Production of MTPA from methionine and KMBA

Addition of L-methionine to broth cultures of $X$. campestris pv. manihotis always resulted in an accumulation of MTPA and MTAA in the culture. After $48 \mathrm{~h}$, concentrations were approximately $1.61 \mathrm{mM}$ for MTPA and $0 \cdot 28 \mathrm{~mm}$ for MTAA (Table 1). Equimolar replace-

\section{Table 1. Conversion of various sulphur-containing compounds to MTPA and MTAA by cultures of $X$. campestris pv. manihotis}

Data were obtained after $84 \mathrm{~h}$, i.e. in the late stationary phase of growth. The values given are means of three replicates. ND, Not detected.

\begin{tabular}{lcccc}
\hline \hline $\begin{array}{c}\text { Potential } \\
\text { precursor }\end{array}$ & $\begin{array}{c}\text { Precursor } \\
\text { concentration } \\
(\mathrm{mM})\end{array}$ & $\begin{array}{c}\text { Bacterial } \\
\text { growth } \\
\left(\mathrm{OD}_{600}\right)\end{array}$ & $\begin{array}{c}\text { MTPA } \\
\text { production } \\
(\mathrm{mM})\end{array}$ & $\begin{array}{c}\text { MTAA } \\
\text { production } \\
(\mathrm{mM})\end{array}$ \\
\hline L-Methionine & 3.35 & 3.06 & $1.70 \pm 0.05$ & $0.27 \pm 0.03$ \\
KMBA & 3.35 & 3.03 & $1.31 \pm 0.03$ & $0.13 \pm 0.02$ \\
D-Methionine & 3.35 & 2.30 & $1.01 \pm 0.04$ & $0.08 \pm 0.02$ \\
L-Cysteine & 3.30 & 2.80 & ND & ND \\
Sodium sulphate & 3.30 & 0.40 & ND & ND \\
\hline \hline
\end{tabular}




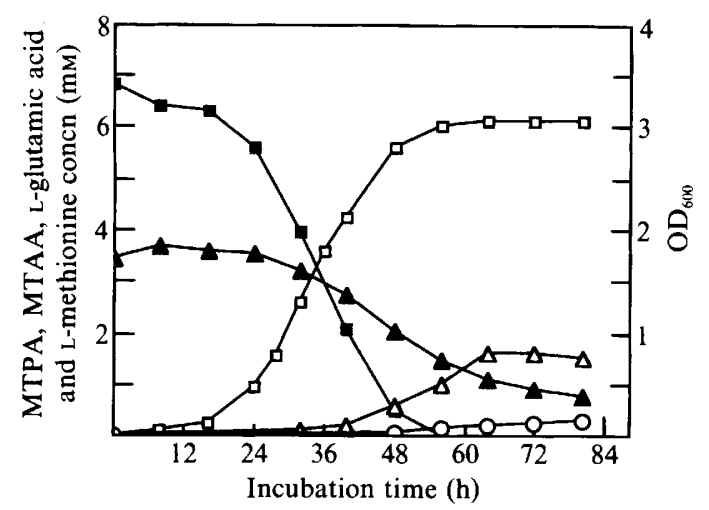

Fig. 1. Relationship between bacterial growth ( $\square$ ), assimilation of methionine $(\Delta)$ and glutamic acid $(\square)$, and production of MTPA $(\triangle)$ and MTAA (O). Bacteria were grown for $84 \mathrm{~h}$ in $50 \mathrm{ml}$ of a modified Watanabe broth at $28^{\circ} \mathrm{C}$ on a gyratory shaker operating at 150 r.p.m.

ment of L-methionine by its D-enantiomer or its $\alpha$-keto acid analogue (KMBA) also resulted in MTPA and MTAA production, though in smaller amounts (Table 1 ). None of these were detected in basal medium supplemented with L-cysteine or sodium sulphate.

In Watanabe broth containing L-methionine and Lglutamic acid, the assimilation curve of L-methionine showed a good temporal correlation with the production curve of MTPA (Fig. 1). Assimilation of methionine was delayed approximately $16 \mathrm{~h}$ with regard to bacterial growth and glutamic acid uptake (Fig. 1). No trace of KMBA was detected in the medium during any stage of bacterial growth. Methionine consumption and MTPA production were not affected by the absence of Lglutamic acid in the medium.

\section{Demonstration of methionine conversion into MTPA}

When a bacterial suspension was incubated for $2 \mathrm{~h}$ at $30^{\circ} \mathrm{C}$ with $4 \mu \mathrm{mol} \mathrm{L}-\left[3,4-{ }^{-14} \mathrm{C}\right]$ methionine, the radiochromatogram of fractions collected after HPLC showed three discernible peaks identified by comparing the retention time with standards (Fig. 2). The first peak, eluting between fractions 20 and 28 (retention time 4.35 $\mathrm{min}$ ), was residual unmetabolized $\mathrm{L}-\left[3,4^{-14} \mathrm{C}\right]$ methionine. The second, at fractions 31 to 36 , was MTPA (retention time $6.35 \mathrm{~min}$ ). A third small peak corresponding to MTAA was discernible between fractions 42 to 46 (retention time $8.61 \mathrm{~min}$ ). No radioactive KMBA was found when bacteria were incubated with $\mathrm{L}-[3,4-$ ${ }^{14} \mathrm{C}$ ]methionine alone. In order to detect this presumed metabolic intermediate, a trapping pool of cold KMBA $(2 \mu \mathrm{mol})$ was added in conjunction with $4 \mu \mathrm{mol} \mathrm{L}-[3,4-$ $\left.{ }^{14} \mathrm{C}\right]$ methionine and incubated under standard conditions with bacteria. This complementation by KMBA induced a $2 \cdot 35$-fold decrease of radioactivity incorpor-

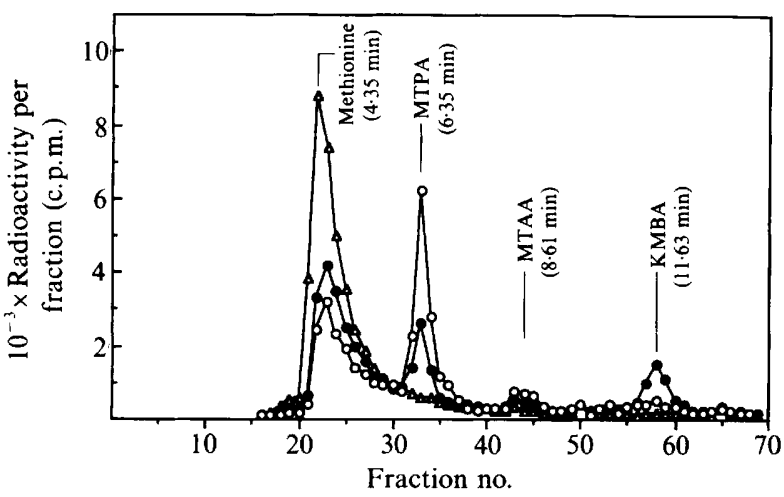

Fig. 2. HPLC elution profiles of radioactive compounds contained in supernatants from $X$. campestris pv. manihotis incubations. Bacterial suspensions ( $4.66 \mathrm{mg}$ protein $\left.\mathrm{ml}^{-1}\right)$ were incubated for $1 \mathrm{~h}$ with $(\Theta)$ or without $2 \mathrm{mM}-\mathrm{KMBA}(\mathrm{O})$ in $25 \mathrm{ml}$ Erlenmeyer flasks containing $4 \mathrm{mM}$ $\mathrm{L}-\left[3,4-{ }^{14} \mathrm{C}\right]$ methionine $(1 \mu \mathrm{Ci})$ and $14 \mathrm{~mm}$-potassium phosphate buffer $(\mathrm{pH} \mathrm{7.2)}$ in a final volume of $1 \mathrm{ml}$. For the control $\triangle(\triangle) 0.5 \mathrm{ml} 2 \mathrm{M}$ $\mathrm{HClO}_{4}$ was added at the start of the incubation.

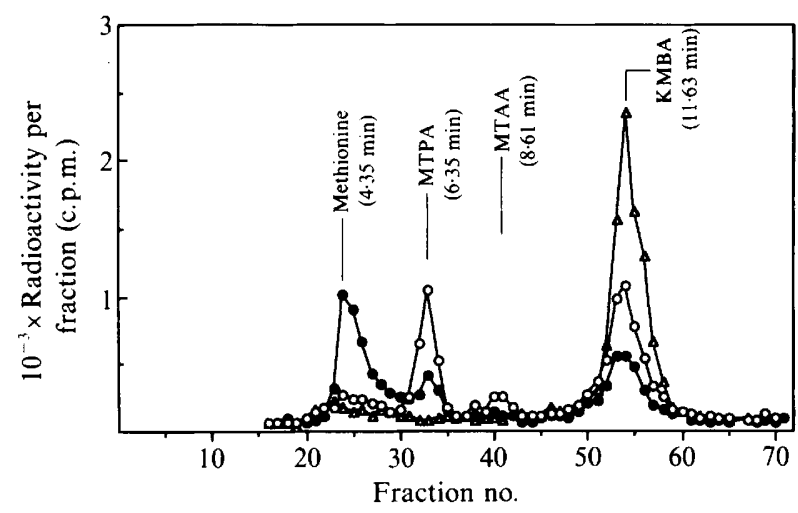

Fig. 3. HPLC elution profiles of radioactive compounds contained in supernatants from $X$. campestris pv. manihotis incubations. Bacterial suspensions (5.96 mg protein $\mathrm{ml}^{-1}$ ) were incubated for $1 \mathrm{~h}$ with $(O)$ or without $2 \mathrm{mM}$-L-methionine $(\mathrm{O})$ in $25 \mathrm{ml}$ Erlenmeyer flasks containing $2.5 \mathrm{~mm}-\left[3,4-{ }^{14} \mathrm{C}\right] \mathrm{KMBA}(0.5 \mu \mathrm{Ci})$ and $14 \mathrm{mM}$-potassium phosphate buffer ( $\mathrm{pH} 7.2)$ in a final volume of $1 \mathrm{ml}$. For the control $(\triangle) 0.5 \mathrm{ml} 2 \mathrm{M}$ $\mathrm{HClO}_{4}$ was added at the start of the incubation.

ated in MTPA, a virtual disappearance of MTAA, and the appearence of a fourth radioactive peak eluting at fractions 54 to 61 (retention time $11.63 \mathrm{~min}$ ) corresponding to the KMBA. Radioactive MTPA, MTAA and KMBA were never detected when bacteria were omitted from the mixture or initially killed by $2 \mathrm{M}-\mathrm{HClO}_{4}$. On the basis of the recoveries of radioactivity and the methionine specific activity, the production rate of MTPA was estimated to be $3 \cdot 1 \mathrm{nmol} \mathrm{min}^{-1}(\mathrm{mg} \text { protein })^{-1}$.

Incubation of bacteria with $\left[3,4^{-14} \mathrm{C}\right] \mathrm{KMBA}$ for $2 \mathrm{~h}$ under standard conditions led to the formation of radioactive MTPA and MTAA, but only traces of $\left[{ }^{14} \mathrm{C}\right]$ methionine were detected in the radiochromatogram of the mixture (Fig. 3). When the mixture 
Table 2. Effect of $A O A A$ on the production recoveries of $\left[{ }^{14} \mathrm{C}\right] M T P A$ and $\left[{ }^{14} \mathrm{C}\right] M T A A$

\begin{abstract}
$\mathrm{L}-\left[3,4-^{14} \mathrm{C}\right]$ Methionine $(1.5 \mu \mathrm{Ci}, 2 \mathrm{mM})$ or $\left[3,4^{-14} \mathrm{C}\right] \mathrm{KMBA}(0.5 \mu \mathrm{Ci}, 2 \mathrm{mM})$ were incubated for $1 \mathrm{~h}$ in flasks containing bacterial suspension $\left(5.42 \mathrm{mg}\right.$ protein $\left.\mathrm{ml}^{-1}\right), 14 \mathrm{mM}$-potassium phosphate buffer $(\mathrm{pH} 7 \cdot 2)$, with or without $0.2 \mathrm{mM}$-AOAA, in a final volume of $1 \mathrm{ml}$. Incubation mixtures were analysed by HPLC, fraction collection and subsequent liquid scintillation counting as described in Methods. Similar results were obtained in one repetition of this experiment.
\end{abstract}

\begin{tabular}{|c|c|c|c|c|c|c|c|}
\hline \multicolumn{2}{|c|}{ Labelled substrate } & \multirow{2}{*}{$\begin{array}{l}\text { Addition at } \\
\text { the start of } \\
\text { incubation }\end{array}$} & \multirow{2}{*}{$\begin{array}{c}\text { Total }{ }^{14} \mathrm{C} \\
\text { recovery } \\
(\%)^{*}\end{array}$} & \multicolumn{4}{|c|}{${ }^{14} \mathrm{C}$ recoveries $(\%)$ in HPLC fractions of $: \dagger$} \\
\hline Type & $\begin{array}{c}\text { Amount } \\
(\mu \mathrm{Ci})\end{array}$ & & & $\begin{array}{l}\text { Methionine } \\
(20-28)\end{array}$ & $\begin{array}{l}\text { KMBA } \\
(54-61)\end{array}$ & $\begin{array}{l}\text { MTPA } \\
(31-36)\end{array}$ & $\begin{array}{l}\text { MTAA } \\
(42-46)\end{array}$ \\
\hline $\mathrm{L}-\left[3,4^{-14} \mathrm{C}\right]$ Methionine & $\begin{array}{l}1 \cdot 5 \\
1 \cdot 5 \\
1 \cdot 5\end{array}$ & $\begin{array}{l}\mathrm{H}_{3} \mathrm{PO}_{4}(2 \mathrm{M}) \\
\text { None } \\
\text { AOAA }(0.2 \mathrm{mM})\end{array}$ & $\begin{array}{l}89 \cdot 1 \\
92 \cdot 5 \\
94 \cdot 0\end{array}$ & $\begin{array}{l}82 \cdot 0 \\
44 \cdot 7 \\
72 \cdot 8\end{array}$ & $\begin{array}{l}0 \cdot 0 \\
0 \cdot 0 \\
0 \cdot 0\end{array}$ & $\begin{array}{r}0.0 \\
19 \cdot 4 \\
0.6\end{array}$ & $\begin{array}{l}0 \cdot 0 \\
3 \cdot 2 \\
0 \cdot 0\end{array}$ \\
\hline$\left[3,4^{-14} \mathrm{C}\right] \mathrm{KMBA}$ & $\begin{array}{l}0.5 \\
0.5 \\
0.5\end{array}$ & $\begin{array}{l}\mathrm{H}_{3} \mathrm{PO}_{4}(2 \mathrm{M}) \\
\text { None } \\
\text { AOAA }(0.2 \mathrm{mM})\end{array}$ & $\begin{array}{l}71 \cdot 5 \\
80 \cdot 6 \\
77 \cdot 6\end{array}$ & $\begin{array}{l}7 \cdot 1 \ddagger \\
15 \cdot 0 \\
11 \cdot 3\end{array}$ & $\begin{array}{l}61 \cdot 5 \\
11 \cdot 7 \\
20 \cdot 2\end{array}$ & $\begin{array}{l}4 \cdot 0 \ddagger \\
52 \cdot 4 \\
45 \cdot 6\end{array}$ & $\begin{array}{l}0 \cdot 0 \\
6 \cdot 2 \\
6 \cdot 1\end{array}$ \\
\hline
\end{tabular}

* Percentage of radioactivity recoverd in the sample before HPLC analysis.

$\dagger$ Numbers in parentheses are the fractions in which the compound was recovered.

$\ddagger$ Traces of $\left[{ }^{14} \mathrm{C}\right]$ methionine and $\left[{ }^{14} \mathrm{C}\right] \mathrm{MTPA}$ contaminants in the radioactive $\left[3,4-{ }^{14} \mathrm{C}\right] \mathrm{KMBA}$ prepared according to the method developed by Mitchell \& Benevenga (1978).

contained both $\left[3,4^{-14} \mathrm{C}\right] \mathrm{KMBA}$ and cold L-methionine $(2 \mu \mathrm{mol})$ there was a 1.52-fold decrease in the recovery of radioactivity into MTPA, while $25 \%$ of the total radioactivity was incorporated into the methionine pool (Fig. 3). The production of $\left[{ }^{14} \mathrm{C}\right] \mathrm{MTPA}$ and/or $\left[{ }^{14} \mathrm{C}\right]$ methionine from $\left[3,4-{ }^{14} \mathrm{C}\right] \mathrm{KMBA}$ was, as above, strictly associated with bacterial metabolism.

AOAA at a concentration of $0 \cdot 2 \mathrm{~mm}$ totally inhibited production of $\left[{ }^{14} \mathrm{C}\right]$ MTPA by a bacterial suspension incubated with L- $\left[3,4-{ }^{14} \mathrm{C}\right]$ methionine (Table 2). On the other hand, incubation of the bacteria with [3,4$\left.{ }^{14} \mathrm{C}\right] \mathrm{KMBA}$ and AOAA still led to the accumulation of radiolabelled MTPA in the mixture. In this latter case, production of $\left[{ }^{14} \mathrm{C}\right]$ MTPA was reduced by only $8 \%$ compared to bacteria incubated in absence of AOAA. At the same time, the consumption of KMBA was reduced by about the same amount $(8.5 \%)$. Similar relationships were observed for the MTPA-associated production of MTAA.

A release of ${ }^{14} \mathrm{CO}_{2}$ was recorded by radiorespirometry when bacterial suspensions were incubated with $\mathrm{L}-[1$ $\left.{ }^{14} \mathrm{C}\right]$ methionine for $1.5 \mathrm{~h}$, but no radioactive MTPA was detected in the mixture at the end of the run. The rate of ${ }^{14} \mathrm{CO}_{2}$ production increased with temperature, from 10 to $30^{\circ} \mathrm{C}$, according to the Arrhenius relationship; an activation energy of $55.6 \mathrm{~kJ} \mathrm{~mol}^{-1}$ was calculated for the microbiological system involved in the decarboxylation. At $30^{\circ} \mathrm{C}$, with a mixture containing $1 \mu \mathrm{mol} \mathrm{L}$-methionine, the decarboxylation rate of the amino acid was $2.25 \mathrm{nmol} \mathrm{min}^{-1}$ (mg protein) ${ }^{-1}$.

\section{Discussion}

This work establishes for plant pathogenic bacteria the catabolic sequence by which methionine is converted into MTPA, a reportedly phytotoxic organic acid. As in the experiment done by Robeson \& Cook (1985), the absolute requirement of methionine for MTPA production and the incorporation of radioactivity from $L-[3,4-$ ${ }^{14} \mathrm{C}$ ]methionine into MTPA demonstrate the occurrence of a metabolic link between these two compounds. The release of ${ }^{14} \mathrm{CO}_{2}$ and the absence of incorporation of radioactivity into MTPA from $\mathrm{L}-\left[1-{ }^{14} \mathrm{C}\right]$ methionine indicate that one step of the pathway leading to the production of MTPA is decarboxylation of methionine. Moreover, the fact that KMBA undergoes biotransformation to MTPA, the difficulties in detecting its accumulation in vitro and the need to use a trapping pool of cold KMBA to observe incorporation of radioactivity from $\mathrm{L}-\left[3,4-{ }^{-14} \mathrm{C}\right]$ methionine into KMBA suggest that KMBA is an intermediate in the overall biotransformation process. Incubation of bacteria with either $\mathrm{L}-[3,4-$ $\left.{ }^{14} \mathrm{C}\right]$ methionine or $\left[3,4-{ }^{14} \mathrm{C}\right] \mathrm{KMBA}$ demonstrate the reality and reversibility of a bioconversion between these two compounds, suggesting a transaminase activity. From these results, transamination of methionine into KMBA and subsequent decarboxylation into MTPA is proposed as the catabolic sequence for production of the phytotoxin. Evidence for this was provided by adding the transaminase inhibitor AOAA (Rognstad \& Clark, 1974) to the incubation mixture. Production of $\left[{ }^{14} \mathrm{C}\right]$ MTPA from $\mathrm{L}-\left[3,4-{ }^{14} \mathrm{C}\right]$ methionine was totally inhibited by AOAA, whereas production of $\left[{ }^{14} \mathrm{C}\right] \mathrm{MTPA}$ from $\left[3,4-{ }^{14} \mathrm{C}\right] \mathrm{KMBA}$ was unaffected. These results accord with the catabolic pathway described by Steele $\&$ Benevenga (1978) for eukaryotes (rat or monkey liver cells). Extension of this catabolic sequence to some other amino acids (leucine, isoleucine, phenylalanine and 
tryptophan) is in accordance with the production of low molecular mass carboxylic acids observed for $X$. campestris pv. campestris (Robeson \& Cook, 1985) and pv. manihotis (Ewbank \& Maraite, 1990).

Ince \& Knowles $(1985,1986)$ described the formation of ethylene from methionine by cultures or cell-free extracts of Escherichia coli. They demonstrated that the first step of the process implied the production of KMBA by transamination of methionine (Ince \& Knowles, 1986). On the other hand, many plant pathogenic bacteria belonging to the genera Erwinia, Pseudomonas and Xanthomonas show increased production of ethylene in the presence of methionine (Swanson et al., 1979). Methionine could therefore be involved via its conversion to KMBA in a dual metabolic role, leading to the production of phytotoxins (MTPA and MTAA) and to excessive production of the phytohormone ethylene. Further investigation could determine more precisely the basis of pathogenicity of Xanthomonas spp.

E. E. is a Research Assistant for FNRS (Belgium). HPLC equipment was supported by FNRS grant no. 1.5.448.88F.

\section{References}

Arima, K., Yamashita, T., Hosoda, J. \& Tamura, G. (1970). Studies on substances active on the behaviour of planarian. I. Production of trans-3-methylthioacrylic acid and 3-methylthiopropionic acid by microorganisms. Agricultural and Biological Chemistry 34, 11781183.

Berthet, J. A. \& Bondar, G. (1915). Molestia bacteriana da mandioca. Boletim de Agricultura São Paulo 16, 513-524.

CASE, G. L. \& BENEVENGA, N. J. (1976). Evidence for $S$-adenosylmethionine independent catabolism of methionine in the rat. Journal of Nutrition 106, 1721-1736.

Dixon, J. L. \& Benevenga, N. J. (1980). The decarboxylation of $\alpha$ keto- $\gamma$-methiolbutyrate in rat liver mitochondria. Biochemical and Biophysical Research Communications 97, 939-946.

DYE, D. W. (1962). The inadequacy of the usual determinative test for the identification of Xanthomonas spp. New Zealand Journal of Science 5, 393-416.

EWbank, E. \& Maraite, H. (1990). Amino acid catabolism in Xanthomonas campestris pathogenesis. Proceedings of the VIIth International Conference on Plant Pathogenic Bacteria, Budapest, 1116 June 1989 (in the Press).

HolmberG, B. (1945). Zur Kenntnis der Propiothetine. Archiv für Kemi, Mineralogi Och Geologi, BD 21, 7.
INCE, J. E. \& KNOWLES, C. J. (1985). Ethylene formation by cultures of Escherichia coli. Archives of Microbiology 141, 209-213.

INCE, J. E. \& K NOWLES, C. J. (1986). Ethylene formation by cell-free extracts of Escherichia coli. Archives of Microbiology 146, 151-158.

MARAITE, H. \& MEYER, J. A. (1975). Xanthomonas manihotis (ArthaudBerthet) Starr, causal agent of bacterial wilt, blight and leaf spots of cassava in Zaïre. Pest Articles and News Summaries 21, 27-37.

MAYAudon, J. (1971). Use of radiorespirometry in soil microbiology and biochemistry. In Soil Biochemistry, vol. 2, 202-256. Edited by A. Douglas Mclaren \& J. Skuyns. New York: Marcel Dekker.

Mitchell, A. D. \& Benevenga, N. J. (1978). The role of transamination in methionine oxidation in the rat. Journal of Nutrition 108, $67-$ 68.

Noda, T., Soto, Z., Kobayashi, H., Iwazakis, S. \& OKuda, S. (1980). Isolation and structural elucidation of phytotoxic substances produced by Xanthomonas campestris pv. oryzae. Annals of the Phytopathological Society of Japan 46, 663-666.

PerreauX, D., Maraite, H. \& Meyer, J. A. (1982). Identification of $3-$ methylthiopropionic acid as a blight-inducing toxin produced by Xanthomonas campestris pv. manihotis. Physiological Plant Pathology 20, 313-319.

Perreaux, D., Maratte, H. \& Meyer, J. A. (1986). Detection of 3methylthiopropionic acid in cassava leaves infected by Xanthomonas campestris pv. manihotis. Physiological and Molecular Plant Pathology 28, 323-328.

Robeson, D. J. \& Cook, D. R. (1985). Production of low molecular weight carboxylic acids by Xanthomonas campestris pv. campestris in relation to the amino acid composition of the medium and their possible involvement in pathogenesis. Physiological Plant Pathology 26, 219-230.

Rognstad, R. \& Clark, D. G. (1974). Effects of aminooxyacetate on the metabolism of isolated liver cells. Archives of Biochemistry and Biophysics 161, 638-646.

Spackman, D. H., Moore, S. \& Stein, W. H. (1958). Automatic recording apparatus for use in the chromatography of amino acids. Analytical Chemistry 30, 1190-1206.

Steele, R. D. \& Benevenga, N. J. (1978). Identification of 3methylthiopropionic acid as an intermediate in mammalian methionine metabolism in vitro. Journal of Biological Chemistry 253, 78447850.

StickLAND, L. H. (1951). Determination of small quantities of bacteria by means of the biuret reaction. Journal of General Microbiology $\mathbf{5}$, 698-703.

Swanson, B. T., Wilkins, H. F. \& Kennedy, B. W. (1979). Factors affecting ethylene production by some plant pathogenic bacteria. Plant and Soil 51, 19-26.

Watanabe, T., Sekizana, Y. \& Oda, M. (1967). Biochemical studies of the host-parasite relationship between Xanthomonas oryzae and rice plant. I. Sulphur containing amino acid as an essential growth factor of the bacterium. Annals of the Phytopathological Society of Japan 30, $1-7$.

Young, J. M., Dye, D. W., Bradbury, J. F., Panagopoulos, C. G. \& RoBBs, C. F. (1978). A proposed nomenclature and classification for plant pathogenic bacteria. New Zealand Journal of Agricultural Research 21, 153-177. 